\title{
The Power of the Local in Sports Broadcasting: A Cross-Cultural Analysis of Rugby Commentary
}

\author{
Fabrice Desmarais and Toni Bruce \\ University of Waikato, New Zealand
}

\begin{abstract}
This article explores how local pressures intersect to produce differing broadcasts in 2 cultural contexts. This is achieved via a cross-cultural analysis of a decade of televised rugby union matches between France and New Zealand and interviews with leading commentators in both countries. The authors argue that although the overarching commercial imperative to capture audiences might be the same in both countries, and despite global tendencies toward homogenized presentation of sports events, there are local differences in expectations about which kinds of audiences should be captured, and these lead to different practices and emphases in the live broadcasts. The authors suggest that in each country, broadcasts are the result of a complex set of pressures that interact to produce broadcasts with "local" flavor and characteristics.
\end{abstract}

Keywords: sports media, France, New Zealand, audience

The symbiotic relationship between sport and television is widely acknowledged and has been the focus of considerable academic attention since the beginnings of television in the 1950s (e.g., Barnett, 1990; Coakley, 1999; Oriard, 2001; Rowe, 2004; Wenner, 1989; Whannel, 1992). However, the production of live sports broadcasts has remained an underresearched area (c.f., Desmarais \& Bruce, 2008; Gruneau, 1989; MacNeill, 1996; Silk, 2001; Silk, Slack, \& Amis, 2000; Stoddart, 1994). In particular, live commentary has received relatively little academic attention, although some studies have investigated historical aspects (Whannel), linguistic elements (Bowcher, 2003; Ferguson, 1983; Kuiper \& Haggo, 1985; Wanta \& Leggett, 1988), or the ways in which gender (e.g., Billings, Angelini, \& Eastman, 2005), racial and ethnic (Billings, 2003; Bruce, 2004), and nationalistic ideologies are expressed by commentators (Billings \& Eastman, 2002; Pociello, 1999; Sabo, Jansen, Tate, Duncan, \& Leggett, 1996). In addition, most research focuses on North America or Europe and on global sports such as tennis, golf, or the Olympic Games.

In the sport of rugby union, analyses of commentary are rare (e.g., Bassett, 1984, 1987; Pociello, 1999). Furthermore, although some cross-cultural research

Desmarais is with the Dept. of Management Communication, and Bruce, the Dept. of Sport and Leisure Studies, University of Waikato, New Zealand. 
has been conducted in relation to general media coverage of specific sports events or individuals (e.g., Alabarces, Tomlinson, \& Young, 2001; Nakamura, 2005; Wong \& Trumper, 2002), cross-cultural studies of live commentary are similarly rare (e.g., Larson \& Riverburg, 1991), perhaps because of language and datacollection challenges faced by researchers working across cultures. This lack of cross-cultural studies is a pity because such studies are perfect tools to denaturalize taken-for-granted conventions within cultures that could not be as easily uncovered in single-culture studies.

\section{The Appeal of Mediated Sports}

Television, sport, and advertising have been described as a ménage à trois that creates a profitable show business (Beck \& Bosshart, 2003) in which television producers' main concern is "to prevent viewer boredom" (Morris \& Nydahl, 1985, p. 109). Having realized that "no screen sport can just rely on its assumed intrinsic appeal" (Rowe, 2004, p. 190), television has systems in place that aim to retain and increase its audience to sell advertising at a premium price around the mediated event (see Bassett, 1984, 1987; Duncan \& Brummett, 1987; Shilbury, Quick, $\&$ Westerbeek, 2003). These systems incorporate extra technological elements such as slow motion, instant replay, sound, and close-up images, elements of a process that makes the televised experience something that successfully competes with the stadium experience (see Barnett, 1990).

On its own, however, the enhanced technological experience that televised sport offers does not guarantee that viewers will stay tuned for the entire length of a sport event or that they will become faithful, regular viewers. Therefore, television channels seek to hook and retain precious viewers not only via the technologization of the sport event, including processes of visual selection and representation (see Barnett, 1990; Bruce, 2005; Gruneau, 1989; Rowe, 2004), but also via its theatricalization achieved through commentary.

\section{The Role of Commentary}

The commentator's main role is, therefore, to use vocal stimuli to retain committed viewers while also catching the "uncommitted viewing eye" (Rowe, 2004, p. 185). ${ }^{1}$ In this process, the commentator's expertise and enthusiasm act as important communication tools for television channels, greatly promoting and enhancing a televised sport event and potentially increasing its audience because of the added value of the commentator's interpretations of on-field actions.

Studies have shown that listening to announcers is one of numerous motivations for watching mediated sport and is "a factor in the enjoyment of televised sport" (Comisky, Bryant, \& Zillman, 1977, p. 153; Wenner \& Gantz, 1989). Few people could imagine watching their favorite mediated sporting events without commentary, in part because the commentators' voices bring clearer meaning to the kaleidoscope of images and sounds that make up live sports coverage. This is done via description and dramatization of the action, providing historical and contextual information, evaluating performance and game flow, and maintaining audience interest by adding suspense (see Bender, 1994; Comisky et al.; Bryant, 
Comisky, \& Zillmann, 1977; Whannel, 1992). Commentators also have an important role in turning the technological mix "of slow-motion, instant replay and close-up images, graphics and high-quality sound into a coherent narrative that is a large part of the enjoyment of mediated sports" (Bruce, 2005, p. 1188). David Rowe (2004) summarizes what is required of the sports commentator:

To enhance the experience of watching by various means-through poetic powers of description and evocation . . . to provide supplementary information ... to supply the kind of "insider," expert knowledge that is gained by playing sport at the highest levels. (p. 122)

Commentators are constantly under pressure to maintain the right balance between information and entertainment, managing the somewhat contradictory task of objectively presenting a "real" game that is at the same time highly mediated and structured to retain viewers. In this process commentary adds an additional layer of meaning to the event, providing added value to the images and rigorously linguistically framing what we see. The images we see of the actions on screen can be taken, as Chion (1994) argues, to be "puppet[s] animated by the anchorman's voice" (p. 7). In fact, Comisky et al. (1977) showed via audience research that viewers do "get caught up in the way the sportcaster interprets the game" and that "dramatic commentary affects perception of play" (p. 153). In this study we were interested in investigating what differently culturally situated commentary might provide to its viewers and how commentators' own beliefs influence how they frame events.

\section{Methods}

We recorded 15 broadcasts of rugby matches between France and New Zealand telecast on a variety of free-to-air and satellite stations in both countries between 1994 and 2004. These included one state-owned, free-to-air channel in each country (France 2 and TV One), both of which rely on advertising revenue; one commercial free-to-air channel in each country (Tf1 and TV3); and one subscription satellite broadcaster (Sky Television in New Zealand). On all channels the advertising pattern was similar; advertising occurred before and after the game and during halftime, but no advertising occurred during game play. The games were analyzed by researchers who were fluent in French and English and familiar with each national rugby context. Our main focus was on the form, content, and amount of commentary. In particular, we considered how commentators in each nation envisioned their own rugby team (themselves) and the opposition team (the "other"). Thematic coding was carried out by means of multiple viewings and replay of the video footage. To better contrast the New Zealand and French commentary, the coders initially broke down each game into 10-minute segments, first analyzing the New Zealand commentary and then the corresponding French one. As in other similar research, consensus was achieved via discussion. ${ }^{2}$

The thematic analysis was extended by interviews with six well-known and experienced rugby commentators who called most of the analyzed games. Playby-play commentators included Pierre Salviac of France and Keith Quinn, Grant Nisbett, and John McBeth of New Zealand. Interviews with expert analysts 
included ex-players Pierre Albaladejo (who played for France from 1954 to 1967) and Murray Mexted (who played for the New Zealand All Blacks from 1979 to 1985). Semistructured interviews (see Bailey, 1994; May 1997) including openended questions classified into five sections (on commentators' training, perceptions of the public, sense of cultural identity, the craft of commentary, and tradition and change) provided us the advantage of being able to probe beyond the initial answers and invite interviewees to expand on specific issues while also providing sufficient structure and standardization for comparability between respondents' answers. The aim of the questions was to arrive at a clearer understanding of the cultural and institutional factors that support and structure rugby commentary in both countries. Therefore, even though each commentator might consider his own contribution to be unique, this study contends that commentators are subjects of their cultures and communicate through the cultural and national discourses that predominate within them (Desmarais \& Bruce, 2008). Indeed, we agree with Hall (1997) that "it is discourse, not the subjects who speak it, which produce knowledge. Subjects may produce particular texts, but they are operating within the limits of the episteme, the discursive formation, the régime of truth, of a particular period and culture" (p. 55).

In research such as this, which attempts to gain insights into the culturally specific processes of live sports television production, interviews are useful tools to explore the relation between texts and their conditions of production, or what Charaudeau (1983) calls discourse circumstances. These conditions of production include the material and institutional environment of discourse and the "sets of institutional routines" (Fairclough, 1995, p. 48) that tend to generate ready-todecode material (Bourdieu, 1996). The interview process was therefore vital in gaining insights into the specific processes of production as experienced by the encoders of texts (commentators, in this case). As a complement to the analysis of texts, these insights fostered an understanding of commentators' assessments of their own institutional place (Pêcheux, 1969) and of the pressures that shape sport commentary-for example, commentators' visions and "assumptions about the audience" (Hall, 1993, p. 92).

Pêcheux's (1969) concept of imaginary formation was particularly useful in our investigation of the relationship between commentators and their audiences. According to Pêcheux, how people imagine themselves and their interlocutor in terms of role and image in the communication process is part of an imaginary formation that depends on questions encoders ask themselves about the people (viewers, in this case) with whom they are communicating. Encoders always make hypotheses about the knowledge of decoders, decoders' expectations of what they should say and how they should say it (Charaudeau, 1983), and their role in the communication process. Our interviews with commentators shed light on the constraints that are part of the conditions of production and that codify sociolinguistic practices of commentary in each cultural environment. We were able to investigate the perceptions that commentators have of their communication contract (Charaudeau, 1994) with their culturally and nationally situated decoders and to decrypt the imaginary formations they have of the audience. 


\section{Traversing the Local: Differences in Commentary}

The different cultural position of rugby in each country has an important influence on how commentators imagine and therefore address their national audiences (see Desmarais \& Bruce, 2008). Briefly, in New Zealand there is little doubt that rugby has been a key site for the construction of a shared national identity (Bassett, 1990; Fougere, 1989; Nauright, 1992; Perry, 1994; Phillips, 1996). It has long been mobilized in support of the national myth of New Zealand as a unified society (Phillips). Indeed, rugby is widely accepted as the national sport in New Zealand, and mass viewing of international matches played by the men's national team, the All Blacks, has been "a significant ritual in New Zealand life" (Day, 1999, p. 100).

In France, rugby has never been part of a major or consistent discourse of national success (Dine, 2001), even though support rises temporarily for the Six Nations Championship and has been high for rugby world cups, especially the 2007 World Cup in France. Rugby is strongly linked to the culture and traditions of the Southwest, including good food, singing, comradeship, and other traditional sports such as bullfighting. Even at the elite level, the tendency in France has been to portray rugby as part of a tradition of fun rather than competition (Adole, 2002; Albaladéjo, 1999; Sansot, 1990; Tillinac, 1999). Since 1995, when rugby turned professional, French literature on rugby has consistently portrayed it as being torn between the advent of professionalism reserved for an elite and its attachment to traditional rural values. Through the literature there is a sentiment that with professionalism, rugby is moving too fast toward productivity, planning, performance, and profitability and is losing touch with the culture that has nourished it up to now (Adole; Lombard, 2003; Rey, 1997; Tillinac). ${ }^{3}$

Rugby's status in each nation leads to differences in how the game is packaged visually and linguistically for television. Our analysis found six areas in which coverage differed between the two nations. These included the length of broadcasts, the commentators' conceptions of their audiences, the amount of commentary, the pace and volume of commentary, and the tone and specific focus of commentary. As we will argue, these six areas of notable difference reflect the different cultural contexts in which the commentators operate and point to the power of the local context in framing coverage.

\section{Differences in Lengths of Broadcasts}

These differing understandings of rugby's place in national culture are part of the discursive contexts in which rugby broadcasts are produced, and they result in marked differences in how much time is dedicated to broadcasting live games. New Zealand broadcasts clearly reveal the importance given to rugby in its national culture. Regardless of channel, and for the last 15 years at least, All Blacks matches have included a prematch buildup that can last up to 1 hour, along with extended live analysis after the game, not to mention a wide range of highlights, preview and review shows, and regular television news coverage. The 
prematch coverage includes a review of previous confrontations between the teams, dissection of statistics, debates over the suitability and quality of different players, and comments by current and former players, coaches, and analysts. All these elements, which can double the actual duration of the live match, are part of the standard procedure for packaging the game for the New Zealand public. In addition, they work to reinforce and amplify the status of the game, while also creating valuable space for advertisers who wish to target a mass audience.

In stark contrast, because rugby is not closely linked to French nationalism, French coverage of international rugby matches starts a few minutes before the game and finishes immediately afterward. ${ }^{4}$ Rugby has to compete for media time with other more central concerns and, therefore, is given a strictly limited amount of time on air. Thus, French audiences are given access only to the event as it plays out on the field. With virtually no buildup and no advertising breaks during games, except at halftime, this sport offers fewer possibilities than in New Zealand for advertisers to take advantage of the event.

\section{Conceptions of the Audience: A Balancing Act}

In his historical study of commentary on the BBC, Whannel (1992) noted that "how commentators should talk was determined by a concept of whom they were trying to talk to" (p. 30). Indeed, in rugby as in any other sport, to capture and hold an audience it is necessary to create commentary that connects with it. Successful commentary must relate to the level of knowledge, expectations, and range of gratifications that audiences bring to and seek from their viewing experiences. Commentary is also a constant job of reconciling opposites in that, on the one hand, there is a wish to be unobtrusive for the expert audience, and, on the other hand, there is a need to educate an audience of novices while actively building entertainment (Brookes, 2002; Rowe, 2004; Whannel).

Our study revealed that commentators in both countries understood the need to connect with a myriad of audiences who might potentially switch off and saw their commentary as a balancing act of communicating to different groups. However, there were important differences in New Zealand and French commentators' imaginary formations of their audiences in relation to knowledge of the sport, geographical spread, and the importance of entertainment. ${ }^{5}$

In New Zealand there was a consensus among commentators that their audience had a rather high level of rugby knowledge and that it was "getting more so all the time." In a country where rugby is considered the major sport, the New Zealand audience was imagined as mostly "involved and knowledgeable." As one commentator pointed out, "Knowledgeable, yes. Everybody has an opinion on rugby, it doesn't matter who you talk to. . . . Let's face it, it's a religion isn't it? I mean we all know that." However, the balancing act of commenting in New Zealand was made even more delicate by commentators' imaginings of another type of viewer whom they saw as constituting the bulk of the audience: those who "believe that they know everything about rugby." As one long-time commentator put it, the audience in New Zealand could be divided into three: "Those who don't know much, those who know a lot, and those who think they know a lot," further arguing ironically that "those who think they know a lot are very high in this country." These imaginings of an audience that mostly perceived itself as expert had a 
major influence on commentators' communication balancing act, forcing them to communicate in restrained and subtle ways, such as mostly trying "not to offend the people who do know a lot and these over here that think they know a lot" and trying "to do it in a subtle way ... just half a sentence, 'knock-on there, so it will be a scrum for the restart with the defending team ball,' thank you."

New Zealand commentators also acknowledged that the balancing act involved educating an audience of people "who don't know everything about rugby." This latter group was identified as primarily new immigrants, "some youngster who is just getting to the age where he or she is starting to watch it," and "women and families getting involved . . . because it's become much more attractive since the professional game came into being." These new viewers were therefore considered emergent stakeholders whom commentary had to address as part of a strategy to widen and expand the audience.

In the French context, commentators also acknowledged that they had to navigate between different types of audiences. However, educating viewers was higher on the agenda than in New Zealand. French commentators believed that the French commentary's mission was to entertain and educate a broad national audience spread throughout the country that had only a superficial knowledge of rugby. As one commentator noted, "We work on a generalist channel, we work for a public that can come and watch rugby on television as entertainment, not necessarily as connoisseurs, so we've got this role. . . [Rugby is] a secondary sport in France."6

In the actual commentaries this assumption about the low level of audience knowledge resulted in the French expert consultant spending a lot of his time describing basic elements of the game such as rules and explaining referees' calls. Our analysis found that French commentary mostly acted as a beginners' guide to the sport, an approach borne out in the interviews. For France's foremost commentator what is expected of the French consultant is

that spontaneously he explains why the referee made a call and consequently what was the rule, secondly he explains the game justifying such and such a move or criticizing such and such a move, and explaining why such options might have been more interesting for the game.

Similarly, the long-time expert commentator noted that "these little details made things interesting. Why there was a long touch, why they played a short one, why the halfback was so close to his forwards or far from them."

In contrast with New Zealand commentators, French commentators imagined their audience as first and foremost needing to be entertained by commentary. Interviews revealed that French commentators' vision of their work was based on naturalized beliefs about their position in the rugby world. French commentators had a deep-seated cultural vision of themselves as standing out in what they saw as the Anglo-Saxon-dominated world of rugby. They attributed their different entertaining and garrulous approach to commentary to their Latin as opposed to Anglo Saxon character. Their comments were often based on a discourse that justified communication behavior according to cultural origins and that meant that they felt they should act accordingly in their rugby commentary. As one commented, "The Latins have a certain verve and a certain humor as well. Because for 
us, rugby, we always believe that it is there to have fun, so our commentaries are a bit more based on fun than others." In other words they gave natural cultural, almost biological, differences as a reason for the peculiarity in their approach to communication. ${ }^{7}$

The impact of tradition was also important in the French context. The core audience was imagined as the sons and daughters of people who had experienced the more storytelling and entertaining style of commentary of France's first celebrity commentator, Roger Couderc. ${ }^{8}$ Clearly, Couderc's success and strong legacy still affected the communication contract that French commentators had with the French public. For instance, a French commentator acknowledged that, although he used Scotsman Bill McLaren as a model for the technical part of his commentaries, historical and cultural forces meant that he had to adapt his communication to the French audience:

This means I had to use his descriptive rigor in the statistics, in the anecdotes, but I also had to adapt it because the French public is not an Anglo Saxon public, the French public was raised to the sound of "Allez les petits!" [Go little ones!], so with superficial things, and was not ready to digest a mass of statistical information, for example, so I watered down the statistical and adapted my commentary specifically to the culture of French rugby and French viewers.

As well as having to connect with a large audience not necessarily familiar with the game, the difficulty identified by French commentators was also being able to connect with a regional core of aficionados located in the Southwest, the region renowned as the heart of French rugby. That knowledgeable audience was imagined as having a strong traditional family following, handed down from one generation to the other. This geographical location of the expert audience is in stark contrast with the New Zealand context (imagined by commentators as a coherent national audience without any geographical divisions) and has led French commentary to address the question of commentators' credibility in a unique way. Indeed, one noteworthy element of the packaging of French rugby was that the commentary box invariably included at least one commentator with a strong southern accent.

Voice carries elements that add considerable meaning to the act of communication. Researchers such as Pittam (1994) and Laver (1994) have shown that tone, pitch of voice, or accent can work indexically, signaling, or being made to signal, not only attitudinal information but also status and age, among other things. In French rugby commentary, accent was clearly used as a signifier of authenticity and rugby knowledge. This institutionalized production technique has the advantage of anchoring the broadcast in its heartland (the South); providing connotations of expertise, especially for the less knowledgeable; and positioning the person with the accent as an authority assumed to know. This unusual communication strategy would also positively resonate with the southwestern audience, stroking the ego of the "experts," as rugby is the only place in the French media where that particular accent takes on connotations of expertise. Furthermore, it would help avoid criticism from that expert audience (see Rowe, 2004). ${ }^{9}$ 


\section{Amount of Commentary}

In the first period of our analysis, when rugby was still officially an amateur sport, we found marked differences in how much commentators spoke during the game. In 1994, when each country featured only two commentators, our analysis shows that French commentators spoke through almost all $(91 \%)$ of the live action, whereas the New Zealand commentators were silent for more than one third of the coverage, speaking during only $63 \%$ of the live action. In other words, the French commentators talked about $30 \%$ more than their New Zealand counterparts.

By 2000, 5 years after rugby turned fully professional, both countries had added one person to their commentary teams. An extra sideline commentator was added to the French broadcasts, and New Zealand included another expert analyst in the commentary booth. The French sideline commentator had little input into the French commentary, but the New Zealand analyst's comments were given as much importance as the two existing commentators. However, even though New Zealand broadcasts used three full-time commentators during this period, the French commentary was still more talkative (90\% vs. $81 \%)$. The $18 \%$ increase in New Zealand commentary was a result of the additional expert in the commentary booth rather than the existing commentators' speaking more. These differences in the amount of talking can in part be explained by the location of rugby in national culture and commentators' assumptions about the level of knowledge of their audiences. They also need to be understood in relation to the focus of commentary.

\section{Focus of Commentary}

New Zealand: A Focused, Analytical, and Serious Approach. To hold a nationally situated audience it is necessary for commentary to connect with it, relate to the range of gratifications national viewers seek, and emphasize these. We suggest that the New Zealand focus on not offending a perceived expert audience resulted in notably less commentary. New Zealand commentary was extremely focused on the game and approached it in a serious way, reflecting the importance of the game in the national imagination. As a result of the New Zealand commentators' understanding of an educated and intensely interested audience that saw the game as an important event, their commentary contained little explanation of technical terms or discussion of why certain choices were made by players. Instead they tended to let the game unfold without comment and let the action speak for itself much more than French commentators did. This sober and rather low-key approach with plenty of space left for viewers to make sense of the action could be one way to appear less annoying to, and avoid criticism from, an expert audience (see also Rowe, 2004) that is possibly grounded in a tradition of understated, laconic male conversation (Phillips, 1996).

Central to New Zealand commentary was advice to the team and directions about, or assessments of, strategy on how to dominate or win the match. For example, "that's what they've got to do," "this is how they should play," or "they've got to turn them." The New Zealand commentators also took a more analytical and dispassionate approach than the French, focusing on what was expected to be a 
foregone conclusion: a win for the All Blacks. One of the major satisfactions a national audience seeks in sport is winning (see Gantz, 1981). Indeed, this appears to be especially true in New Zealand, where there was a strong perception among the New Zealand commentators that "New Zealanders . . . feel like they deserve to win. And that's different from other countries." One commentator argued that winning was the most important thing for New Zealanders,

because we are a small country in the scheme of things. Big time, if you live in New Zealand, you know that. Well, most people do. You understand you are a small country, a long, long way away from anywhere apart from Australia ... and for us to be able to perform on the world stage to the level that we have done for 100 years, we are very proud of it and so, therefore, we desire and need ... our national team to continue to perform well.

New Zealand commentators perceived an important tension in the national audience caused by fear of not winning. Not only were they aware of the broader media hype that surrounded every All Blacks match, but some also appeared to resent the uncertainty and tension that such buildups created as background for their own work:

TV New Zealand news . . . ran a piece about the fighting that was going to take place in this game against France, and the interviewer bloke . . . said, "Well, we are not taking a backward step" but he was on edge . . . and that all whips up a kind of edginess in the public and of course when we win ... there is this great euphoria about winning. It sets us OK for a while but only until the next big game comes up and then the edge will start again.

Thus, the interviews revealed that New Zealand commentators felt that they were given the responsibility of commentating on more than a game of sport. Instead, international rugby matches were events of national importance that would symbolically maintain the country's prominence in, if not dominance of, the rugby world. This perception encouraged them to develop their commentary in a manner that recognized the importance and cultural significance of the televised event.

France: An Entertaining, Multidimensional Approach. French commentary, on the other hand, was not only more talkative but also less focused on the game. The more voluble French approach to commentary seemed to be grounded in the relatively marginal status of rugby in France. Because of the tradition of entertainment around rugby and because rugby is not central to French identity, it is not necessary to take the game particularly seriously. As a result, commentators consistently provided linguistic entertainment throughout the game, even in the tensest moments. For instance, reflecting the Southwest focus on enjoying life and the pleasures of eating and drinking (e.g., Adole, 2002; Terret, 1999; Tillinac, 1999), the French commentary often digressed from the action on the field to subjects only tangentially related to rugby, such as food and drink or sports such as bullfighting that are connected to the Southwest. Rhyming jokes or very colloquial speech, such as Ça le gonflait un peu d'être sur le banc des remplaçants [He was slightly pissed off to be on the bench], were not uncommon. Linguistic references to Occitan, the dialect of the Southwest, were also systematically included. French 
commentary also contained much stronger imagery and metaphorical and regional language, as well as use of onomatopoeia and puns. Some of these, coined by the commentators or inspired by Occitan, have become nationally famous, such as $L a$ cabane est tombée sur le chien [The shed fell on the dog] and Les mouches ont changé d'ane [The flies have switched donkeys].

In stark contrast to the New Zealand commentators, the French commentators believed that the French public considered rugby entertainment first and an important sports event second (see also Adole, 2002; Desmarais \& Bruce, 2008; Sansot, 1990; Tillinac, 1999. In a country where rugby is not as important to its global recognition, commentators felt that the French viewers would rather see their team play with style and lose than play poorly and win. This perception is consistent with Pociello's (1999) observation that

in rugby, a sport that is a spectacular "war of the styles," there is a strong preference by French people for "effervescent" and "acrobatic" backlines, launched in their dishevelled mad rushes, disconcerting, inventive, audacious. . . . In France in all domains, whether in mind games, in literature or in sport, we have always been attached to style. (p. 88)

One commentator supported this argument, claiming that French viewers enjoy French wins,

when they play rugby that conforms to the photographic images that . . the other teams have given of them-[as] the inventors of French flair. They want to hear the people say about them that they are different by the way they are playing-more spectacular to watch than the others. In the same way that they like to think that they are the best people in the world at making love, I think the French people who follow rugby like to think that the rugby practiced by the French team is the most spectacular in the world.

Thus, the commentators' understandings reflect broader French conceptions of Frenchness as embodying flair and spectacular play (Desmarais \& Bruce, 2008; O’Donnell, 1994; Pociello, 1999).

\section{Tone: Communicating Cheerfulness Versus Communicating Power}

The French cultural passion for style and the different significance given to the concept of winning meant that French commentators spent a lot of time taking the role of somebody cheering alongside the players and fans and communicating their enthusiasm about risky, flamboyant play to their public; hence the difference in commentary volume and pace. Whereas New Zealand commentators encouraged their team rationally, giving advice on how to overcome the adversary and therefore ultimately win, French commentary encouraged its team via enthusiasm and cheerfulness rather than logic, as if to raise the spirits of the audience and appeal to the viewers' hearts rather than primarily to their minds. For example, Aah la belle balle! [Ooh the beautiful ball!], Allez ça fait du bien [Right, it feels good], or Bon, allez les bleus, c'est le moment, il reste 3 minutes [OK, go the Blues, it's time now, there's 3 minutes left]. 
This commentary based on enthusiasm and cheerfulness meant that French commentators used a faster pace of commentary than their New Zealand counterparts. They accompanied tries or backline actions via the speed and volume of commentary, increasing speed as the action evolved, using their voices to convey excitement and pleasure in good play ("Ouaihhh!!" "Olé Olé," "Oh la la la la la la qu'il est beau!') and changing speed as the action evolved. One of New Zealand's most experienced commentators had once listened to a French broadcast and noted this difference. Describing a specific sequence in the game, he said,

It was a great French try which swept the length of the field . . . and their commentary increased as the tempo of the movement got better and better and better, and they were shouting . . . and as it got better and better there were just two voices going hell for leather, over the top of each other ... both going at the same time and to my ear it sounded wonderful.

On the other hand, variations in New Zealand commentary were not as much based on speed as on a change in vocal quality. The use of stereotypical masculine and authoritarian voice attributes such as depth and loudness to connote power, strength, manliness, and dominance has been noted by Desmarais (2002) in the context of New Zealand television advertising. In New Zealand rugby commentary, there was also "the growling effect" that gives the masculine voice "a touch of gruntiness" (Desmarais, p. 162). As one commentator explained, "People wouldn't put up with a person with a high voice, a squeaky voice. I think there has got to be a good timbre to it." It was clear that New Zealand commentators adjusted their pitch of voice "for the purpose of paralinguistic communication" (Laver, 1994, p. 155) to reflect and emphasize the power of an action or of a player (e.g., violent encounters such as tackles or powerful runs over defenders) by deepening their voices rather than by speeding up the pace of communication as their French counterparts did. As one New Zealand commentator described it, the New Zealand approach was "measured" and used "pitch of voice" to convey excitement. ${ }^{10}$

\section{Conclusion}

Overall this study highlights the power of the local in commentary for international sport events. Based on analysis of rugby commentary in two countries, we discovered that commentators produce different versions of the same event, framing each match for a nationally situated public and adding local meaning to it. For live commentary to capture and retain these viewers it needs to be entertaining and address public expectations. Thus, if commentators want to be able to connect with and deliver audiences to the television channels for which they work, it is vital that they understand the specific cultural location of those audiences.

Unlike French commentators, who believed their audience was mainly a mass audience with only a superficial knowledge of the game, New Zealand commentators believed that they were mostly addressing people who had-or thought they had - a high level of knowledge about the game. Both audience conceptions had clear implications for how commentators communicated with their viewers. As a result, New Zealand commentary was less descriptive and explicatory but also 
more serious, analytical, and purely focused on the game than the French commentary, which was more multidimensional, digressing easily onto subjects not related to rugby, and more based on fun and on cheering.

Therefore, given the strength of naturalized cultural and linguistic norms within which French and New Zealand commentators work, rapid changes in the cultural specificity of commentary are relatively unlikely. It would be difficult, for instance, for New Zealand commentators to connect with their audiences by using the same volume and pace of commentary as their French counterparts or by conveying notions of fun during an event that is considered by New Zealanders to be very significant for them and their country. Indeed, stepping outside established discourse and changing local commentary conventions would be equivalent to taking a considerable communication risk.

Commentary always reflects the particular conditions under which it is produced, including current broadcasting conventions, the cultural status of the particular sport being broadcast, developments in technology, and broader social changes. For example, changes in a sport's cultural position can shift over time. It is possible, for instance, that rugby in New Zealand could shift to a less central position, which could affect the form, focus, and content of commentary. On the other hand, should the French rugby team become more important to French identity, commentary could change to reflect that centrality, shifting, for example, from a focus on entertainment to a more serious approach.

In a world in which global media and entertainment conglomerates increasingly control the content and delivery of sports events and in which global sports competitions take place across national boundaries, there is a fear that mediated live sport will become homogenized, with local control and flavor disappearing in favor of an "increasingly indistinguishable" sports product (Law, Harvey \& Kemp, 2002, p. 299). In contrast, this study revealed that specific national cultures dictate how commentators view and address their audiences. Indeed, violation of audiences' expectations about commentary could potentially alienate them. Commentators know this and, under the influence of their specific culture, tend to produce and reproduce commentary that tries to successfully meet those expectations.

\section{Notes}

1. The pressure to attract new viewers without alienating existing fans is not always successful, as was seen in Fox Television's failed experiment with an illuminated puck in ice hockey (see Mason, 2002).

2. The authors would like to thank Alex Ramon, a research assistant who was involved with the initial coding. The authors would also like to thank the two anonymous reviewers for their helpful feedback.

3. Although there was concern in New Zealand about rugby becoming a professional sport in 1995, the national team has always been highly professional and competitive in its approach to the game.

4. Except for important postpool, sudden death Rugby World Cup games.

5. We note that although the commentators occasionally identified gender as an element in their conceptions of the audience, in both countries they differentiated among audience types based more strongly on levels of knowledge about the game rather than explicitly in terms of 
gender. In addition, despite the clearly multiethnic composition of both national teams, there was no discussion of racial differences in commentator perceptions of the audience. This should not be surprising because extensive research on media coverage of nation-versus-nation competitions demonstrates that internal divisions (such as gender and ethnicity) tend to be obscured in media coverage, which, instead, highlights the unity of the nation (e.g., Alabarces et al., 2001).

6. International rugby has traditionally been broadcast on France 2, a state-owned generalist channel, except on the occasion of the 1999 and 2007 World Cups, when TF1, a commercial channel, bought the broadcasting rights. This shift generated debates, especially about the excessive commercial packaging of the game by TF1 and the change in commentators. TF1's soccer commentator was put in charge of commenting on rugby games at the 2007 World Cup, and many aficionados saw this as an affront to their sport.

7. The use of relatively crude binary oppositions is a common element in commentary (Pociello, 1999). In both countries commentators also used them as a way to differentiate themselves from others in the rugby world (Desmarais \& Bruce, 2008).

8. Roger Couderc was the first significant rugby commentator. Couderc's commentary is regarded as having popularized rugby to the point where "in three years the public was totally ablaze" (Verdier, 1996, p. 26). He was nicknamed the 16th man on the French team (see Garcia, 1993) because his commentary often incorporated overt and enthusiastic support for the national team. His trademark line, Allez, les petits! was typical of his enthusiastic and patriotic commentary. His verve and humor (which he also used in his wrestling commentary) created a tradition of garrulous commentary. Couderc was later teamed with Pierre Albaladéjo, who had been working on radio and was France's first expert analyst.

9. For these linguistic reasons and thanks to his clear pedagogical explanations, Albaladéjo was an extremely successful commentator nationwide, able to connect with both the southern expert audience and the less knowledgeable.

10. Although research on commentary in other sports, such as cricket, hockey and American football, and in other countries, such as the United States and United Kingdom, suggests that commentary might differ along a range of dimensions such as education versus entertainment, or speed and tone (see Barnett, 1990; Bruce, 2005), our focus was on how commentary on the same sport in two different countries might show differences resulting from each specific cultural context.

\section{References}

Adole, J. (2002). Mon sac de rugby. Bayonne, France: Editions Atlantica.

Alabarces, P., Tomlinson, A., \& Young, C. (2001). Argentina versus England at the France '98 World Cup: Narratives of nation and the mythologizing of the popular. Media Culture \& Society, 23(5), 547-566.

Albaladéjo, P. (1999). Les mouches ont changé d'ane. Paris: JC Lattès.

Bailey, K.D. (1994). Methods of social research (4th ed.). New York: The Free Press.

Barnett, S. (1990). Games and sets: The changing face of sport on television. London: BFI.

Bassett, G. (1984). Screen play and real-play: Manufacturing sport on television. Sites, 9, 5-31.

Bassett, G. (1987). Discourse, ideology, and the delivery of audience: Television's representation of one day cricket. Sites, 14, 57-72.

Bassett, G. (1990, January). Masculinity and the representation of sport on television. Paper presented at the Commonwealth and International Conference on Physical Education, Sport, Health, Dance, Recreation and Leisure, Auckland, New Zealand.

Beck, D., \& Bosshart, L. (2003). Sport and media. Communication Research Trends, 22(4), $3-43$. 
Bender, G. (1994). Call of the game: What really goes on in the broadcast booth. Chicago: Bonus Books.

Billings, A.C. (2003). Portraying Tiger Woods: Characterizations of a "Black" athlete in a "White" sport. The Howard Journal of Communications, 14, 29-37.

Billings, A.C., Angelini, J.R., \& Eastman, S.T. (2005). Diverging discourses: Gender differences in televised golf announcing. Mass Communication \& Society, 8(2), 155-171.

Billings, A.C., \& Eastman, S.T. (2002). Gender, ethnicity, and nationality: Formation of identity in NBC 2000 Olympic coverage. International Review for the Sociology of Sport, 37(3-4), 351-368.

Bourdieu, P. (1996). Sur la télévision. Paris: Liber éditions.

Bowcher, W.L. (2003). Speaker contributions in radio sports commentary. Text, 23(4), 445-476.

Brookes, R. (2002). Representing sport. London: Arnold.

Bruce, T. (2004). Marking the boundaries of the "normal" in televised sport: The play-byplay of race. Media Culture \& Society, 26(6), 861-879.

Bruce, T. (2005). Play-by-play announcing. In D. Levinson \& K. Christensen (Eds.), Berkshire encyclopedia of world sport (Vol. 3, pp. 1188-1193). Great Barrington, MA: Berkshire.

Bryant, J., Comisky, P., \& Zillmann, D. (1977). Drama in sports commentary. The Journal of Communication, 27(3), 140-149.

Charaudeau, P. (1983). Langage et discours: Eléments de sémiolinguistique (théorique et pratique). Paris: Hachette Université.

Charaudeau, P. (1994). Le contrat de communication de l'information médiatique. In T. Lancien (Ed.), Le Français dans le monde (pp. 8-19). Paris: EDICEF.

Chion, M. (1994). Audio-vision: Sound on screen (C. Gorbman, Trans.). New York: Columbia University Press.

Coakley, J.J. (1999). Sport in society: Issues and controversies (5th ed.). St. Louis, MO: Mosby.

Comisky, P., Bryant, J., \& Zillman, D. (1977). Commentary as a substitute for action. Journal of Communication, 27(3), 150-153.

Day, P. (1999). Sport, the media and New Zealand. In B. Patterson (Ed.), Sport, society and culture in New Zealand (pp. 93-102). Wellington, New Zealand: Stout Research Centre.

Desmarais, F. (2002). Authority versus seduction: The use of voice-overs in New Zealand and French television advertising. In J. Farnsworth \& I. Hutchinson (Eds.), New Zealand television: A reader (pp. 156-171). Palmerston North, New Zealand: Dunmore.

Desmarais, F., \& Bruce, T. (2008). Blurring the boundaries of sports public relations: National stereotypes as sport announcers' public relations tool. Public Relations Review, 34(2), 183-191.

Dine, P. (2001). French rugby football: A cultural history. Oxford, UK: Berg.

Duncan, M.C., \& Brummett, B. (1987). The mediation of spectator sport. Research Quarterly for Exercise and Sport, 58(2), 168-177.

Fairclough, N. (1995). Media discourse. London: Edward Arnold.

Ferguson, C. (1983). Sports announcer talk: Syntactic aspects of register variation. Language in Society, 12, 153-172.

Fougere, G. (1989). Sport, culture and identity: The case of rugby football. In D. Novitz \& B. Willmott (Eds.), Culture and identity in New Zealand (pp. 110-122). Wellington, New Zealand: GP.

Gantz, W. (1981). An explanation of viewing motives and behaviors associated with television sports. Journal of Broadcasting, 25, 263-275.

Garcia, H. (1993) La fabuleuse histoire du rugby. Paris: Editions de la martinière.

Gruneau, R. (1989). Making spectacle: A case study in television sports production. In L.A. Wenner (Ed.), MediaSport (pp. 134-154). Newbury Park, CA: Sage. 
Hall, S. (1993). Encoding, decoding. In S. During (Ed.), The cultural studies reader (pp. 90-103). London: Routledge.

Hall, S. (1997). The work of representation. In S. Hall (Ed.), Representation: Cultural representations and signifying practices (pp. 13-74). London: Sage.

Kuiper, K., \& Haggo, D. (1985). On the nature of ice hockey commentaries. In R. Berry \& J. Acheson (Eds.), Regionalism and national identity (pp. 167-175). Christchurch, New Zealand: Association for Canadian Studies in Australia and New Zealand.

Larson, J.F., \& Riverburg, N.K. (1991). A comparative analysis of Australian, US and British telecasts of the Seoul Olympic ceremony. Journal of Broadcasting \& Electronic Media, 35, 75-94.

Laver, J. (1994). Principles of phonetics. Cambridge, UK: Cambridge University Press.

Law, A., Harvey, J., \& Kemp, S. (2002). The global sport mass media oligopoly: The three usual suspects and more. International Review for the Sociology of Sport, 37(3-4), 279-302.

Lombard, J.C. (2003). Dieu aime-t-il le rugby? Rennes, France: Eden.

MacNeill, M. (1996). Networks: Producing Olympic ice hockey for a national television audience. Sociology of Sport Journal, 13, 103-124.

Mason, D.S. (2002). "Get the puck outta here!": Media transnationalism and Canadian identity. Journal of Sport and Social Issues, 26(2), 140-167.

May, T. (1997). Social research: Issues, methods and process (2nd ed.). Philadelphia: Open University Press.

Morris, B.S., \& Nydahl, J. (1985). Sports spectacle as drama: Image, language and technology. Journal of Popular Culture, 18(4), 101-110.

Nakamura, Y. (2005). The Samurai sword cuts both ways: A transnational analysis of Japanese and US media representations of Ichiro. International Review for the Sociology of Sport, 40(4), 467-480.

Nauright, J. (1992). Sport and the image of colonial manhood. Canadian Journal of History of Sport, 23(2), 54-71.

O'Donnell, H. (1994). Mapping the mythical: A geopolitics of national sporting stereotypes. Discourse \& Society, 5(3), 345-380.

Oriard, M. (2001). King football: Sport and spectacle in the golden age of radio, newsreels, movies and magazines, the weekly and the daily press. Chapel Hill: University of North Carolina Press.

Pêcheux, M. (1969). Analyse automatique du discours. Paris: Dunod.

Perry, N. (1994). The dominion of signs: Television, advertising, and other New Zealand fictions. Auckland, New Zealand: Auckland University Press.

Phillips, J. (1996). A man's country? The image of the pakeha male-A history (2nd ed.). Auckland, New Zealand: Penguin.

Pittam, J. (1994). Voice in social interaction: An interdisciplinary approach. Thousand Oaks, CA: Sage.

Pociello, C. (1999). Sport et sciences sociales: Histoire, sociologie et prospective. Paris: Editions Vigot.

Rey, J.P. (1997). Qu'ont-ils fait de notre rugby? Paris: Editions Solar.

Rowe, D. (2004). Sport, culture and the media (2nd ed.). Buckingham, PA: Open University Press.

Sabo, D., Jansen, S.C., Tate, D., Duncan, M.C., \& Leggett, S. (1996). Televising international sport: Race, ethnicity, and nationalistic bias. Journal of Sport and Social Issues, 20, 7-21.

Sansot, P. (1990). Le rugby est une fête. Paris: Plon.

Shilbury, D., Quick, S., \& Westerbeek, H. (2003). Strategic sport marketing. Sydney, Australia: Allen \& Unwin.

Silk, M. (2001). The conditions of practice: Television production practices at Kuala Lumpur 98. Sociology of Sport Journal, 18(3), 277-301. 
Silk, M., Slack, T., \& Amis, J. (2000). Bread, butter and gravy: An institutional approach to televised sport production. Culture, Sport, Society, 3(1), 1-21.

Stoddart, B. (1994). Sport, television, interpretation and practice reconsidered: Televised gold and analytical orthodoxies. Journal of Sport and Social Issues, 18, 76-88.

Terret, T. (1999). Learning to be a man: French rugby and masculinity. In T.J.L. Chandler \& J. Nauright (Eds.), Making the rugby world: Race, gender, commerce (pp. 62-87). London: Frank Cass.

Tillinac, D. (1999). Rugby blues. Paris: La Table Ronde.

Verdier, J. (1996). Herrero: Le rugby dans la peau. Toulon, France: Editions plein sud.

Wanta, W., \& Leggett, D. (1988). "Hitting paydirt": Capacity theory and sports announcers' use of clichés. The Journal of Communication, 38, 82-89.

Wenner, L.A. (Ed.). (1989). Media, sports, \& society. Thousand Oaks, CA: Sage.

Wenner, L.A., \& Gantz, W. (1989). The audience experience with sports on television. In L.A. Wenner (Ed.), Media, sports, \& society (pp. 241-270). Thousand Oaks, CA: Sage.

Whannel, G. (1992). Fields of vision: Television, sport and cultural transformation. London: Routledge.

Wong, L., \& Trumper, R. (2002). Global celebrity athletes and nationalism. Journal of Sport and Social Issues, 26(2), 168-194. 